\title{
Overcoming Staff Turnover in the Hospitality Industry using Mobley's Model
}

\author{
Ahmad Rasmi AlBattat (Corresponding author) \\ School of Housing, Building and Planning, Universiti Sains Malaysia \\ Sustainable Tourism Research Cluster (STRC), Universiti Sains Malaysia \\ Pulau Pinang, 11800, Malaysia
}

Tel: 60-1-9595-4499 E-mail: battat_ahmed@yahoo.com

\author{
Ahmad Puad Mat Som \\ School of Housing, Building and Planning, Universiti Sains Malaysia \\ Sustainable Tourism Research Cluster (STRC), Universiti Sains Malaysia \\ Pulau Pinang, 11800, Malaysia \\ E-mail: puadusm.gmail.com

\begin{abstract}
Abdullah Saleh Helalat
Prince Sultan Collage for Tourism and Business, Jeddah, Saudi Arabia P.O. Box 447, Alhamrah Street, Alhamrah district, Jeddah, Saudi Arabia

E-mail: abdullh_petra@yahoo.com
\end{abstract}

Doi:10.5296/ijld.v3i6.4844ＵRL: http://dx.doi.org/10.5296/ijld.v3i6.4844

\begin{abstract}
The turnover crisis has been one of the major problems in the hospitality industry. Regardless of the considerable amount of studies on employee turnover, it is still ambiguous and requires further investigation because of its dependency on human resource in the hospitality industry as part of a service product. This paper provides a theoretical overview of Mobley's model on employees' retention or turnover. The primary purpose of this study is to explain that the applications of the Mobley model can either determine job dissatisfaction leading to job turnover or job satisfaction leading to job retention. This application is an attempt to reduce the effects of such a crisis in local hospitality industry; and findings from literature review indicate that deprived working conditions will lead to dissatisfied employees and they eventually quit employment. The practical implications of Mobley's model guide various organizations in the industry to mitigate the effects of employee turnover and increase employee retention.
\end{abstract}

Keywords: Mobley's model, Turnover, Hospitality, Malaysia

\section{Introduction}

Hospitality is a successful industry due to its remarkable contribution to the economy, in Malaysia specifically and in global generally. As a human based industry, hospitality depends on humans as part of the product, in which, cannot be separated from the service process (Ghazali, 2010). Employee satisfaction and retention are very important challenges that face the success of the industry and, unfortunately, labor turnover crises have been emerging globally in the face of many businesses, including hospitality. According to Lashley (2000), turnover can be realized as an employee movement within an organization regardless of the reasons. Though AKSU (2004) found that turnover rates have considerable passive effects on hospitality performance.

The existing literature reviews the job stressors, job stress, job satisfaction, and the work environment as factors which can dissatisfy people and possibly force them to quit their current 
job Tsaur and Tang (2012), Sharma et al. (2010), Banet et al. (2005), Ornelas and Kleiner (2003), Burke (2003), Elangovan (2001), Burke and Greenglass (2001), Nelson and Burke (2000), Varca (1999), Zohar (1994), Cooper and Cartwright (1994), Pestonjee (1992), (Matteson \& Ivancevich, 1982). Asserted that job stressors refers to role ambiguity, conflict, and work overload. Stress refers to the employee's negative feelings which gains from their work environment. The work environment refers to the work dealing with matters which could affect the employee's experience such as satisfaction and job feelings.

Other studies have examined the environmental and organizational factors on the employee's intention to turnover (Brough \& Frame, 2004; Firth et al., 2004). From Bluedorn's (1982) point of view, collecting data with the intention to leave a current job is more cost effective than collecting data for the actual turnover studies. While Dorfman and Howell (1988), Markus and Kitayama (1991), and Hofstede (1980) concentrated on the cultural issues in the work place, Hofstede (1980) model of the cultural characteristics help to explain the cultural differences between the rational groups in the work environment in different areas of the world.

Turnover intention happens when an employee is faced with a bad working environment with high stress in their current job, which in turn, may give them the intention to quit (Hofstede, 1980). According to Vandenberg and Nelson (1999), the intention to quit refers to the subjective norms affecting an employee to turnover from his current job to another one in the near future. Blau (2000), Bigliardi et al. (2005), Mowday et al. (1982) identified the intention to quit as the individual probability to stay or leave their organization; making the difficult decision to leave the job in the near future. W. Mobley (1982) asserted that most studies have been done through the direct or indirect organizational cost of turnover (Rothwell, 1980).

\section{Literature Review}

\subsection{Turnover Intention}

Turnover intention can be defined as the employee's behaviour to quit from their current job. In reference to Bigliardi et al. (2005), the intention to quit is the behaviour made by an employee on whether they want to stay or leave the organization. Researchers argued that turnover intention is an accurate predictor for an actual turnover crises (Ajzen \& Fishbein, 1980; Gregory et al., 2007). According to Mowday et al. (1979), employees' turnover decisions are usually considered and undertaken with regard to their current job situation.

San Park and Kim (2009) argued that the employee's intention to leave their jobs include the actual thought of quitting from the organization as well as statement with the intent to turnover. Nevertheless, the intention to leave is a behaviour predicting the actual turnover from the current job (Gregory et al., 2007; W. Mobley, 1982; W. Mobley et al., 1978). Many studies' findings have clarified that the actual intention to leave is strongly related to the actual turnover from the organization (W. Mobley et al., 1978; Steel \& Ovalle, 1984).

Many researchers have used the term "turnover intention". Ajzen (1991) suggested in his behaviour theory that the turnover intention is a good behaviour to predict for an actual turnover. Other studies have explained that behavioural intention is closely related to the actual one (Mobley et al., 1978; Newman, 1974). From their point of view, W. H. Mobley et al. (1979) argued that intentions can give a better explanation of the actual turnover and a clear idea about the employees' perception toward turnover (Chiu \& Francesco, 2003).

\subsection{Mobley Model Applications}

The model of March and Simon (1958) was one of the premier models of labour turnover; studying the relationship between the factors affecting the employees' movements to the actual turnover (Bowen \& Siehl, 1997; March, 1991). Beyond that, many studies have been done in 
various areas with many models were developed with regard to turnover (Mobley 1977; W. H. Mobley et al., 1979; Price, 1977). Price presented his turnover model explaining that wages, communications, and centralization are strong variables affecting turnover (Price, 1977). In the same era, Mobley (1977) proposed a turnover model based on the linkage between employee satisfaction and quitting based on: quit thinking, searching other jobs, intention to quit, and actually quitting. It seems that an employee starts thinking about turnover after the case of dissatisfaction from their current job. If an employee finds the cost of turnover is much high and availability of other jobs, they will rethink the idea of leaving their current job (Muchinsky, 1993). Mobley tested his model again by studying hospital employees and found useful results to enhance his model (Mobley et al., 1978).

From his point of view, Pearson (1991) clarified that not only it is difficult to find turnover reasons due to personal issues but also the difficulties that arise from the unanswered questions during the exit interviews conducted by the organizations. Pearson approved Bowey's (1978) learning behaviour process which runs in line with Mobley's model. The model points out that a higher salary and the work environment are merely two of the reasons which make an employee want to quit their current job. Salmon et al. (1999) asserted that pay and supervision are highly agreeable reasons to leave the organization.

Turnover reduction should be taken into consideration of research scholars. Dario (1989) clarified some methods to help the organization cope with turnover crises and as well as reduce its rate. First, that the organization improve the labour selection of recruiting. Second, that salary and wage policies should be evaluated orderly to maintain high valuable labour. Third, a reward system should be established so the labourors will attain recognition according to their good work. Fourth, a supervisory system should be provided to maintain the supervisors' motivation. This will help to predict the problems before it exists in the organization. Finally, a communication system should be enhanced to enable the employees to maintain an acceptable level of contact with the organization (Dario, 1989). These methods were approved by Carrell et al. (1992), Milkovich and Boudreau (1997) who suggested that organizations should increase wages and improve opportunities to enhance job satisfaction.

\section{Methodology}

This study briefly describes the existing literature on job stress, job stressors, job satisfaction, work environments, and cultural characteristics, and the turnover with the intention to quit from a current job which leads to actual turnover using the Mobley model (1977). A theoretical framework is also used to explain the relationship between these variables. 


\section{Theoretical Framework}

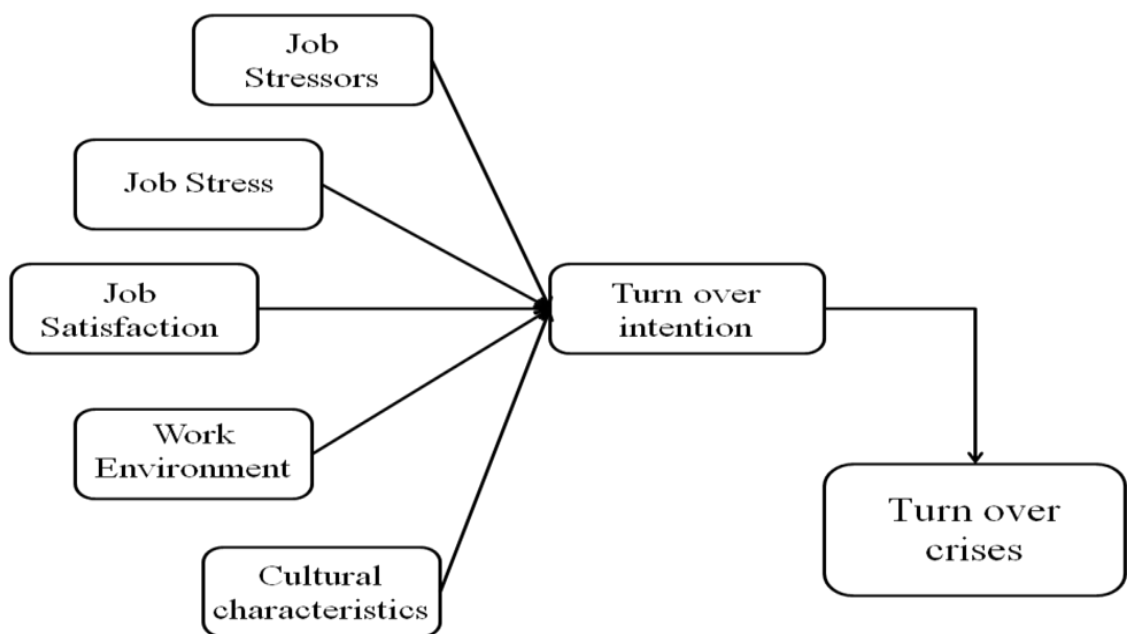

Figure1: Relationship between job stressors and turnover crises

The above framework was adopted from Firth et al. (2004), W. Mobley (1982), Muchinsky (1993), and improved by Banet et al. (2005), Burke (2003), Hom et al. (1984), Lee (1988), Sharma et al. (2010), Zohar (1994) who asserted that job stress, job stressors, work environment and cultural characteristics have an effect on an employee's intention to contribute to a turnover crises.

\section{Findings, Discussion and Conclusion}

Employees' turnover studies have been done from many perspectives. Similar to other industries, the hospitality industry suffers from high turnover rates (Lee-Ross, 1999; Pizam \& Thornburg, 2000). Hospitality managers are important people in the organization who should understand and know how to apply turnover policies in order to reduce the crises effect (W. Mobley, 1982). The turnover levels in the hospitality industry vary from one organization to another by size, type, and geographic location (Hinkin \& Tracey, 2000). Woods and Macaulay (1991) agreed with this argument and asserted that larger deluxe hotels had a lower turnover rate than smaller budget hotels.

Other researchers have clarified that the employee turnover factors in hospitality organizations are being used, such as working nature, labour nature, managers' nature, the efficiency of labour from secondary markets (Boella \& Goss-Turner 2005 ). From his point of view (AKSU, 2004) supported these factors. Hospitality organizations slightly offer a granulated work environment; therefore, a working routine and regular job stress will force an employee to think about evaluating their job.

Considering this as a global problem, researchers have argued that the Malaysian hospitality sector could not escape this problem. Thus, this study aims to identify the Mobley's model and some other labour turnover model applications to the local hospitality industry. Lynn (2002), and Wildes (2007) asserted that understanding turnover causes would help the hospitality sector to reduce the problem and prevent the cause before it becomes a major issue. One way is to provide better work conditions and increased wages.

Malaysia is a multi racial and religious country consisting of three major ethnic groups: Malay, Chinese, and Indian (All Malaysia info, 2011). Wong (2007) mentioned that the Malay ethnic group contributes to 58 percent of the entire population followed by the Malaysian Chinese at 26 percent and the Malaysian Indian at 7 percent. As a multi-racial community, the behavior in labour will be affected by the characteristics of these ethnic groups. According to Abdullah (2001b), managers should be aware of the ethnic values for each one's labour and 
understand its influence in their work. Managers should not take for granted their guidelines when dealing with their labour. Relationship building, focus on labor ethnic groups, respect for the leaders, religious sensitivity, and harmonious workflow all must be carefully considered. Malaysian hospitality managers need to take efficient actions to support the goals and image of the workplace (Abdullah, 2001a).

The results of relative studies fall in line with these findings. Aminuddin (2007) focused on the working hours in the work place. MacHatton et al. (1997) asserted that selection is more important for retaining employees and reducing the turnover crises. Some researchers have advised the stakeholders to use a mentoring program (Lankau \& Chung, 1998). Furthermore, Varoglu and Eser (2006) studied the concept of internal marketing to reduce the crises. Turnover models are aimed to solve the problems before they happen, understand turnover intentions, and find a solution to enhance a positive work environment within the Malaysian hospitality industry.

\section{Acknowledgement}

The authors would like to extend their appreciation to the Universiti Sains Malaysia for the Research University Grant under the Sustainable Tourism Research Cluster STRC entitled 'Tourism Planning' [Grant No. 1001/PTS/8660013] which made this study and paper possible.

\section{References}

Abdullah, A. (2001a). Influence of ethnic values at the Malaysian workplace. Understanding the Malaysian workforce: Guidelines for managers, 1-25.

Abdullah, A. (2001b). Understanding the Malaysian workforce: Guidelines for managers: Malaysian Institute of Management.

Ajzen, I. (1991). The theory of planned behavior. Organizational behavior and human decision processes, 50(2), 179-211.

Ajzen, I., \& Fishbein, M. (1980). Understanding attitudes and predicting social behavior: Prentice-Hall, Eaglewood Cliffs, New Jersy.

AKSU, A. (2004). Turnover costs: research among five-star hotels in the city of Antalya, Turkey. Tourism Analysis, 9(3), 207-217.

All Malaysia info. (2011). Malaysia general info. Retrieved November 13 2012, from http://allmalaysia.info/2011/01/01/malaysia-general-info/

Aminuddin, M. (2007). Human Resource Management: Oxford Fajar Sdn. Bhd.

Banet, Plint, \& Clifford. (2005). Reducing stress and avoiding burnout: A collection of activities for preschoolers. 11(2), 28-32.

Bigliardi, B., Petroni, A., \& Dormio, A. (2005). Organizational socialization, career aspirations and turnover intentions among design engineers. Leadership \& Organization Development Journal, 26(6), 424-441.

Blau, G. (2000). Job, organizational, and professional context antecedents as predictors of intent for interrole work transitions. Journal of Vocational Behavior, 56(3), 330-345.

Bluedorn's, A. C. (1982). A unified model of turnover from organizations. Human relations, $35(2), 135-153$.

Boella , M., \& Goss-Turner, S. (2005 ). Human Resource Management in the Hospitality industry, an introductory guide (8th ed.). Great Britain: Elsevier Butterworth-Heinemann.

Bowen, D. E., \& Siehl, C. (1997). The future of human resource management: March and Simon (1958) revisited. Human Resource Management, 36(1), 57-63.

Bowey's, A. (1978). A guide to manpower planning: Macmillan. 
Brough, P., \& Frame, R. (2004). Predicting Police Job Satisfaction and Turnover Intentions: The role of social support and police organisational variables. New Zealand Journal of Psychology, 33, 8-18.

Burke, R. (2003). Nursing staff attitudes following restructuring: the role of perceived organizational support, restructuring processes and stressors. International journal of sociology and social policy, 23(8/9), 129-157.

Burke, R., \& Greenglass, E. (2001). Hospital restructuring and nursing staff well-being: The role of perceived hospital and union support, Anxiety, Stress and Coping. An International Journal, 14(3), 93-115.

Carrell, M., Kuzmits, F., \& Elbert, N. (1992). Personal Human Resource Management (4th ed.). New York: MacMillan Publishing Company.

Chiu, R. K., \& Francesco, A. M. (2003). Dispositional traits and turnover intention: Examining the mediating role of job satisfaction and affective commitment. International Journal of Manpower, 24(3), 284-298.

Cooper, C., \& Cartwright, S. (1994). Stress-management interventions in the workplace: Stress counselling and stress audits. British Journal of Guidance and Counselling, 22(1), 65-73.

Dario, M. (1989). Personal Manager`s Desk Book. New Jersey: Prentice Hall.

Dorfman, P. W., \& Howell, J. P. (1988). Dimensions of national culture and effective leadership patterns: Hofstede revisited. Advances in international comparative management, 3(127-150).

Elangovan, A. (2001). Causal ordering of stress, satisfaction and commitment, and intention to quit: a structural equations analysis. Leadership \& Organization Development Journal, 22(4), 159-165.

Firth, L., Mellor, D. J., Moore, K. A., \& Loquet, C. (2004). How can managers reduce employee intention to quit? Journal of Managerial Psychology, 19(2), 170-187.

Ghazali, H. (2010). Employee intention to leave a job: A case of Malaysian fast food industry. University of Waikato.

Gregory, D., Way, C., LeFort, S., Barrett, B., \& Parfrey, P. (2007). Predictors of registered nurses' organizational commitment and intent to stay. Health Care Management Review, 32(2), 119-127.

Hinkin, T. R., \& Tracey, J. B. (2000). The cost of turnover. Cornell hotel and restaurant administration quarterly, 41(3), 14-21.

Hofstede, G. (1980). Culture's consequences: International differences in work-related values (Vol. 5): Sage Publications, Incorporated.

Hom, P. W., Griffeth, R. W., \& Sellaro, C. L. (1984). The validity of mobley's (1977) model of employee turnover. Organizational Behavior and Human Performance, 34(2), 141-174. doi: 10.1016/0030-5073(84)90001-1

Lankau, M. J., \& Chung, B. G. (1998). Mentoring for line-level employees. Cornell hotel and restaurant administration quarterly, 39(6), 14-19.

Lashley, C. (2000). Hospitality retail management: A unit manager's handbook: Butterworth-Heinemann, Oxford.

Lee-Ross, D. (1999). Hrm in Tourism and Hospitality: International Perspecives on Small to Medium-Sized Enterprises: Cassell.

Lee, T. (1988). How job dissatisfaction leads to employee turnover. Journal of Business and Psychology, 2(3), 263-271. doi: 10.1007/bf01014043

Lynn, M. (2002). Turnover's relationships with sales, tips and service across restaurants in a chain. International Journal of Hospitality Management, 21(4), 443-447. 
MacHatton, M. T., Van Dyke, T., \& Steiner, R. (1997). Selection and retention of managers in the US restaurant sector. International journal of contemporary hospitality management, 9(4), 155-160.

March, J. G. (1991). Simon. HA (1958). Organizations: New York: Wiley.

March, J. G., \& Simon, H. A. (1958). Organizations.

Markus, H. R., \& Kitayama, S. (1991). Culture and the self: Implications for cognition, emotion, and motivation. Psychological Review; Psychological Review, 98(2), 224.

Matteson, M. T., \& Ivancevich, J. M. (1982). Managing job stress and health: The intelligent person's guide: Free Press New York.

Milkovich, G., \& Boudreau, J. (1997). Human Resource Management (8th ed.). New York: Irwin McGraw-Hill.

Mobley , W. (1977). Intermediate linkages in the relationship between job satisfaction and employee turnover. Journal of Applied Psychology, 62(2), 237.

Mobley, W. (1982). Employee Turnover, Causes, Consequences, and Control: Addison-Wesley.

Mobley, W., Horner, S., \& Hollingsworth , A. (1978). An evaluation of precursors of hospital employee turnover. Journal of Applied Psychology, 63(4), 408.

Mobley, W., Horner, S., \& Hollingsworth, A. (1978). An evaluation of precursors of hospital employee turnover. Journal of Applied Psychology, 63(4), 408-414.

Mobley, W. H., Griffeth , R. W., Hand , H. H., \& Meglino , B. M. (1979). Review and conceptual analysis of the employee turnover process. Psychological bulletin, 86(3), 493.

Mowday, R., Porter, L. W., \& Steers, R. M. (1982). Employee-organization linkages: The psychology of commitment, absenteeism, and turnover (Vol. 153): Academic press New York.

Mowday, R., Steers, R., \& Porter, L. (1979). The measurement of organizational commitment. Journal of Vocational Behavior, 14(2), 224-247.

Muchinsky, P. (1993). Psychology Applied to Work (4th ed.). California: Brooks/Cole publishing company.

Nelson, D., \& Burke, R. (2000). Women executives: Health, stress, and success. The Academy of Management Executive (1993-2005), 14(2), 107-121.

Newman, J. E. (1974). Predicting absenteeism and turnover: A field comparison of Fishbein's model and traditional job attitude measures. Journal of Applied Psychology, 59(5), 610.

Ornelas, S., \& Kleiner, B. (2003). New developments in managing job related stress. Equal Opportunities International, 22(5), 64-70.

Pearson, R. (1991). The human resource: managing people and work in the 1990's. London ; New York: McGraw-Hill.

Pestonjee, D. (1992). Stress and coping: The Indian experience. New Delhi, India: Sage Publication.

Pizam, A., \& Thornburg, S. W. (2000). Absenteeism and voluntary turnover in Central Florida hotels: a pilot study. International Journal of Hospitality Management, 19(2), 211-217.

Price, J. L. (1977). The study of turnover: Iowa State University Press.

Rothwell, J. C. (1980). The Function of the Human Long-latency Stretch Reflex: University of London.

Salmon, J. R., Crews, C., Reynolds-Scanlon, S., Jang, Y., Weber, S. M., \& Oakley, M. L. (1999). Nurse aide turnover: Literature review of research, policy and practice. Tampa, FL: University of South Florida, Florida Policy Exchange Center on Aging.

San Park, J., \& Kim, T. H. (2009). Do types of organizational culture matter in nurse job satisfaction and turnover intention? Leadership in Health Services, 22(1), 20-38. 
Sharma, A., Verma, S., Verma, C., \& Malhotra, D. (2010). Stress and Burnout as Predictors of Job Satisfaction among Lawyers. European Journal of Social Sciences, 14(3), 348-359.

Steel, R. P., \& Ovalle, N. K. (1984). A review and meta-analysis of research on the relationship between behavioral intentions and employee turnover. Journal of Applied Psychology, 69(4), 673.

Tsaur, S.-H., \& Tang, Y.-Y. (2012). Job stress and well-being of female employees in hospitality: The role of regulatory leisure coping styles. International Journal of Hospitality Management, 31(4), 1038-1044. doi: 10.1016/j.ijhm.2011.12.009

Vandenberg, R. J., \& Nelson, J. B. (1999). Disaggregating the Motives Underlying Tiarnover Intentions: When Do Intentions Predict Thrnover Behavior? Human relations, 52(10), 1313-1336.

Varca, P. (1999). Work stress and customer service delivery. Journal of Services Marketing, 13(3), 229-241.

Varoglu, D., \& Eser, Z. (2006). How service employees can be treated as internal customers in hospitality industry. The Business Review, Cambridge, 5(2), 30-35.

Wildes, V. J. (2007). Attracting and retaining food servers: How internal service quality moderates occupational stigma. International Journal of Hospitality Management, 26(1), 4-19.

Wong, L. (2007). Market cultures, the middle classes and Islam: consuming the market? Consumption, markets and culture, 10(4), 451-480.

Woods , R., \& Macaulay, J. (1991). Rx for Turnover: Retention Programs that Work. Cornell Hotel and Restaurant Administration Quarterly, 30(1), 79-90.

Zohar, D. (1994). Analysis of job stress profile in the hotel industry. International Journal of Hospitality Management, 13(3), 219-231. doi: 10.1016/0278-4319(94)90022-1 